\title{
New Standards for Domination and Support Under Section 8(a)(2)
}

\author{
Section 8(a)(2) of the National Labor Relations Act, ${ }^{1}$ which makes \\ it unlawful ${ }^{2}$ for an employer to interfere with, dominate, or sup. \\ port $^{3}$ any labor organization, ${ }^{4}$ has been vigorously enforced to main-
}

1. The National Labor Relations Act (Wagner Act), 1935, ch, 372, $\$ \$ 1.16,45$ Stat. 449 [hereinafter cited as NLRA], as amended by The Labor-Management Relations Act (TaftHartley Act), 1947, ch. 120, \$101 et seg., 61 Stat. 136, further amended by The Labor Management Reporting and Disclosture Act of 1959 (Landrum-Griffin Act), 1'ttb. L. No. 86-257, 1 et seq., 73 Stat. 519 . These statutes are codified at 29 U.S.C. $\$ 141$ et seq. (1970). Section 8(a)(2) provides:

(a) It shall be an unfair labor practice for an employer-

(2) to dominate or interfere with the formation or administration of any labor organization or contribute financial or other support to it: Provided, That subject to rules and regulations made and published by the Board purstant to scction 156 of this title [NLRA $\$ 6]$, an employer shall not be prohibited from permitting employees to confer with him during working hours without loss of pay . . . NLRA $\$ 8(a)(2), 29$ U.S.C. $\$ 158($ a) (2) (1970).

2. A cease and desist order is used in case of a relatively minor violation, and requires an end to employer interference with the labor organization. See, e.g., Regency Electron. ics, Inc., 169 N.L.R.B. 223 (1968); Higgins Industries, Inc., 150 N.L.R.B. 106 (1961). In more serious cases of support under $\$ 8(a)(2)$, the order may require temporary stuspensioul of recognition as the collective bargaining agent, if stch recognition has been given. S'e', e.g., Jack Smith Beverages, Inc., 94 N.L.R.B. 1401 (1951), modificd, $20211.2 \mathrm{~d} 100$ (6tli Cir. 1953), cert. denied, 345 U.S. 995 (1953). In cases of complete domination, the un. ployer is required to disestablish the organization, and is forever barred from recognizing it as the collective bargaining representative. See, e.g., Carpenter Steel Co., 76 N.L.R.1B. 670 (1948). The Board has broad discretion concerning the nature of its remedies. NLKA $\$$ 10(a), (c), 29 U.S.C. $\$ 160$ (a), (c) (1970).

3. Domination and support cases are filed under both the specific provisions of $\$$ $8(a)(2)$ and also under $\$ 8(a)(1)$ 's more general prohibitions against interference. Sece, e.g., Dennison Mfg. Co., 168 N.L.R.B. 1012 (1967). The latter section provides:

(a) It shall be an unfair labor practice for an employer-

(I) to interfere with, restrain, or coerce employees in the exercise of their rights guaranteed in section 157 of this title [NLRA $\$ 7] \ldots$.

NLRA $\S 8(a)(1), 29$ U.S.C. $\$ 158(a)(1)(1970)$.

Section 8 (a)(1)'s prohibition against interference is interpreted as a blanket restriction on any of the practices particularized in $\$ \S 8(a)(2)$ through $8(a)(5)$. Oberer, The Scienter

Factor in Sections 8(a)(1) and (3) of the Labor Act: Of Balancing, Hostile Motivc, Dogs and Tails, 52 CoRNELL L.Q. 491,493 (1967). Henceforth, references to $\$ 8(a)(2)$ should be read as including $\$ 8(a)(1)$.

4. The NLRA defines a labor organization as follows:

The term "labor organization" means any organization of any kind, or any agency or employee representation committee or plan, in which employees participate and which exists for the purpose, in whole or in part, of dealing with employers con. cerning grievances, labor disputes, wages, rates of pay, hours of employment, or con. ditions of work.

NLRA § 2(5), 29 U.S.C. $\$ 152(5)(1970)$.

This definition was intentionally made broad enough to include not only normal unions, but also employces' committees and employees' representation plans. S. RE1'. No. 573, 74th Cong., Ist Sess. 7 (1935). See pp. 513-14 infra. However, purcly social orgailzations are exempt. Hudson Dispatch, 68 N.L.R.B. 115, 124 (1946). Limployer contcntions 
tain a strict dichotomy between labor and management.5 Yet such a stringent typology is based on assumptions about the labor market and the ideology of the labor movement which may no longer be warranted in substantial sectors of today's economy. This Note will argue that there should be a limited redefinition of the law of domination and support: Where employees are genuinely uninterested in developing traditional union structures, and where the employer acts in good faith, the law should provide for a class of permissibly-assisted labor organizations which would fill the need for more innovative labor-management structures than have hitherto been allowed under $\S 8(a)(2)$. This approach would expand the freedom of choice ostensibly guaranteed by the Act, and thus further its primary goals of industrial justice and tranquillity. ${ }^{6}$

\section{Traditional Standards Under $\S 8(a)(2)$}

\section{A. The Per Se Rule}

Although never made explicit, the traditional standard in $\S 8(\mathrm{a})(2)$ cases is essentially a per se rule. ${ }^{7}$ Any employer support of a labor organization is illegal beyond a certain critical level, ${ }^{8}$ regardless of the character of the challenged organization, ${ }^{0}$ the intent of the employer, ${ }^{10}$

that a challenged organization does not fall within the statutory definition, and for that reason does not constitute a violation, have nearly always failed. See Note, Section $\delta(a) 2)$ : Employer Assistance to Plant Unions and Committees, 9 STAN. L. REv. 351, 353.54 (1957), and cases cited therein. Subsequent amendments to the Act have not altered this defi. nitional breadth. Therefore, for the purposes of $\$ 8(a)(2)$, a labor organization need not meet the internal requirements of the Labor Management Reporting and Disclosure Act of 1959 (Landrum-Griffin Act), 29 U.S.C. $\$ 401$ et seq. (1970), Inyo Lumber Co. of Calif., 129 N.L.R.B. 79 (1960), or even have a formal structure at all, Mark L. Jerri, 128 N.L.R.B. $778(1960)$. Nonetheless, attempting to defend $\$ 8(3)(2)$ complaints on the ground that the challenged organization does not constitute a labor organization has been one of the most enduring (and bootless) employer approaches to this section. Cf. notes $114-15$ infra.

5 . Since 1936, the National Labor Relations Board (NLRB) has disposed of over 17,000 cases involving $\S 8(\mathrm{a})(2)$. 1-35 NLRB, ANN. REP. (1936-70) (figure derived by cumulating the reported number of $\$ 8(2)(2)$ cases for each year).

6. Cf. NLRA $\$ 1,29$ U.S.C. \$ 151 (1970) (Findings and Declaration of Policy).

7. The only explicit standard ever enunciated by the Board is that it decides $\$ 8(a)(9)$ cases on the basis of the "totality" of the circumstances. See note 25 infra.

8. "The general rule has developed that an emplojer is guilty of an unfair labor prac. tice whenever his support or domination of a union has reached the point where it is reasonable to infer that the union is not truly the employees' representative in disputes...." Commerce Clearing House, Guidebook to Labor Relations 149 (1960) (emphasis added). See also M. Forkosch, A Treatise on LABOR LAw 668-72 (1965) and cases cited thercin.

9. NLRB v. Jas. H. Matthews \& Co., 156 F.2d 706 (3d Cir. 1916) ("junior board" in "multiple management" plan); Boyle's Famous Corned Beef Co., I68 N.L.R.B. 299, 303 (1967) (independent union); Weather Seal Inc., 16I N.L.R.B. 1226, 1236.37 (1960) (international union); Poe Machine \& Engineering Co., 107 N.L.R.B. 1372, 1387 (1954) (interim organization).

10. In Northeastern Engineering, Inc., 112 N.L.R.B. 743, 750 (1955), the Board ordered disestablishment despite a specific finding that there was "no proof that the Advisory" Committee was set up with any intention of evading the law or making it a substitute 
or the will of the employees. ${ }^{11}$ Under this per se rule, virtually the only question ever litigated is whether the challenged actions are sufficient to constitute the illegal quantum of support.

In practice, this rigid rule has meant that an employer may be found in violation if he assists in or defrays the costs of elections for a labor organization; ${ }^{12}$ helps in or is present at the drawing of its charter; ${ }^{13}$ arranges for its attorney; ${ }^{14}$ supplies a place ${ }^{15}$ or refreshments for its meeting; ${ }^{16}$ furnishes any direct financial support, ${ }^{17}$ no matter how meager; ${ }^{18}$ provides indirect financial aid, as, for example, from vending machines ${ }^{19}$ or the plant store; ${ }^{20}$ allows the organization to use his safe, ${ }^{21}$ mimeograph machine, ${ }^{22}$ or telephone; ${ }^{23}$ or provides secretarial services. ${ }^{24}$ In short, an employer must leave a union or other labor organization scrupulously alone, or the Board, usually upon the complaint of an outside union or a dissident employee, will force him to do 50.25

for collective bargaining." Accord, NLRB v. Clappers Mfg., Inc., 458 F.2d 414 (\$d Cir. 1972) (violation despite employer's possible "exemplary" intentions). See also p. 519 infra.

11. The fact that employees express a desire to be represented by a labor organization has been said not to be determinative of, or even relevant to, the question of whether that organization has in fact been dominated and assisted by the employer. NLRIB $v$. Newport News Shipbldg. \& Dry Dock Co., 308 U.S. 241 (1939); NLRB v. Brown laper Mill Co., 108 F.2d 867 (5th Cir. 1940), cert. denied, 310 U.S. 651 (1940).

12. See Newman-Green, Inc., 161 N.L.R.B. 1062, 1065 (1966); H \& H Plastics Co., I58 N.L.R.B. 1395 (1966).

13. See Thompson Ramo Wooldridge, Inc., 132 N.L.R.B. 993, 1006 (1961).

14. See Guard Services, Inc., 134 N.L.R.B. 1753 , 1755 (1966).

15. See Dennison Mfg. Co., 168 N.L.R.B. 1012, 1017 (1967); Merrill Transport Co., 141 N.L.R.B. 1089, 1099 (1963).

16. See Kunst d/b/a Connor Foundry Co., 100 N.L.R.B. 146, 150 (1952), enf'd, 202 F.2d 846 (6th Cir. 1953); Standard Transformer Co., 97 N.L.R.B. 669, 671 (1951).

17. See Dennison Mfg. Co., 168 N.L.R.B. 1012, 1017 (1967); Kunst d/b/a Connor Foundry Co., 100 N.L.R.B. 146, 151 (1952), enf'd, 202 F.2d 846 (6th Cir. 1053).

18. See Wyman-Gordon Co. v. NLRB, 153 F.2d 481,482 (1946); Wheeling Steel Corp., I N.L.R.B. 699; 708.09 (1936) (50 cents donation per employee each year held a $\$ 8(a)(2)$ violation).

19. See Utrad Corp., 185 N.L.R.B. No. 49, 75 L.R.R.M. 1069, 1071 (1970); Master Transmission Rebuilding Corp., 155 N.L.R.B. 364, 366, enf'd, 373 F.2d 402 (9th Cir. 1964).

20. See Clark Equipment Co., 12 N.L.R.B. 1469, 1479 (1939).

21. See Crowley Milk Co., Inc., 88 N.L.R.B. 1049, 1061 (1950), modified, 208 F.2d 444 (3d Cir. 1953).

22. See Nutone, Inc., 112 N.L.R.B. 1153, 1170 (1955). Such use may be excused, how. ever, if it is "trivial and isolated." Crompton-Shenandoah Co., Inc., 185 N.L.R.B. 694, 697 (1962).

23. See Shell Oil Co. of Calif., 2 N.L.R.B. 835,847 (1937).

24. See Newman-Green, Inc., 161 N.L.R.B. 1062, 1066 (1967).

25. It is an over-simplification to assert that the examples enumerated in the text outline the parameters of $\S 8(\mathrm{a})(2)$. In fact, the parameters are unknown, because the Board declines to make clear the precise type or amount of assistance necded to trigger a violation. Rather, the Board maintains that it does not view individual actions, but in. stead considers the "totality" of a situation. 2 NLRB ANN. REP. 95 (1937). It is there. fore extremely difficult to find the precise basis for the Board's holding in any case, or to extract from the Board's description of the "totality" those separate actions which, of themselves, will or will not support an 8(a)(2) violation. For this reason, the Board's totality approach has been criticized as "indiscriminate lumping." Note, Section $8(a)(2)$, 
Once sufficient employer assistance is shown, no defense is available. Thus, in NLRB v. Newport News Shipbuilding \& Drydock Co., ${ }^{20}$ the Supreme Court affirmed the disestablishment of an employer-assisted labor organization under 8(a)(2), in explicit disregard of "uncontradicted" findings that the company had "good motives" in assisting the organization, that the organization operated "to the apparent satisfaction of employees," that the company practiced no discrimination or coercion of any kind, that the employees were free to join other labor organizations, and that the organization had solved labor disputes and promoted industrial tranquillity. ${ }^{27}$

While 8(a)(2) actions frequently arise because of the indiscretions of otherwise independent local unions, ${ }^{28}$ the clearest case of the per se rule in action is the Board's unforgiving hostility to in-plant, employersponsored, non-union "employees" committees." "shop committees," "grievance councils," or "employees' representation plans," virtually all such organizations are illegal under the traditional doctrine. $^{30}$ Thus, violations have been found not only where the em-

supra note 4, at 34 . The Board's decisions can in fact be quite unpredictable. Compare Sea Life, Inc., 175 N.L.R.B. 982, 985, 996 (1969) (Examiner dismissed 8(a)(2) change as without "scintilla" of evidence; Board reversed, calling it a "classic" casc) with Hesston Corp., Inc, 175 N.L.R.B. 96, 103 (1969) (Examiner found 8(a)(2) violation on cumulation of evidence; Board dismissed in entirety, unconvinced by "totality"). Thus, no single instance of assistance such as enumerated is technically a violation; rather, it is cridence of a violation. The Board's long record with $8(a)(2)$ cases, hovever, indicates a low level of tolerance for such assistance.

26. 308 U.S. 241,251 (1939).

27. For recent examples of this per se rule at work, see notes $106 \& 107$ infra.

28. See, e.g., Wyco Metal Products, 183 N.L.R.B. No. 93, 74 L.R.R.MI. 1411 (1970) (allowing incumbent union to meet on company property an $8(a)(2)$ violation); Crown Discount Dept. Stores, 172 N.L.R.B. No. 89, 69 L.R.R.M. 1565 (1968) (allowing union organizer to use a room a violation).

29. Generally, an employees' committee is an independent labor organization, unaffiliated with a national union and considerably less formal than even an independent local. Typically, it has a vague structure and purpose, frequently has no dues, by-laws, or constitution, and deals with management on such varied topics as terms and conditions of employment, grievances, safety, recreation, or any other matter. Its distinguishing feature is that the degree of management participation is considerably greater than in more formal unions.

30. See generally Note, Section $\delta(a)(2)$, supra note 4. Sec also Feldman \& Stcinberg. Employee-Management Committees and the Labor-Management Relations Act of 1917, 35 TUL. L. REv. 365, 366 (1961):

A long line of court [and Board] decisions, with no discernible common thread, has stricken down, with apparent mechanical regularity, a succession of plans whereby employers have sought to establish employee-management committees to adjust the multitude of day-to-day shop grievances.

The "common thread," it would seem, is simply the Board's singleminded application of the per se rule.

At first, the NLRB's hostility to this type of organization was institutionalized. It differentiated between unaffiliated independent locals and locals affiliated with national unions by completely disestablishing the former and just temporarily withholding recognition from the latter, in cases of employer assistance. In response to protests that independents could be just as effective as affiliated unions, and ought to be treated equally, Congress included in the Taft-Hartley Act a specific directive that independents vere to 
ployer actually formed the committee, ${ }^{31}$ but also where he caused it to be formed ${ }^{32}$ or where the organization never developed the characteristics of an independent entity, such as a constitution, by-laws, dues, meetings, or collective agreements. ${ }^{33}$ It has been held a violation of 8 (a)(2) to suggest the formation of an employees' committee, ${ }^{34}$ to be its sustaining force, ${ }^{35}$ or to deal with one on an interim basis. ${ }^{30}$ In general, the enduring and singleminded goal of the Board and the courts has been to force the employer to "refrain from any action which will place him on both sides of the bargaining table." 37

\section{B. The Adversary Model of Labor Relations}

During the 1930's there was undoubtedly a need for such an uncompromising rule. In 1935, the year in which the NLRA was enacted, employer-dominated labor organizations such as the "Employee Representation Plans" fostered by the defunct National Industrial Recovery Act accounted for over 2,500,000 workers. ${ }^{38}$ These organizations were, for the most part, patent creatures of management, mere charades of representation which hampered outside organizing, and organized labor fought bitterly to have such "company unions" outlawed forever. ${ }^{30}$ The argument that "collective bargaining becomes a mockery when the spokesman of the employees is the marionette of the employer" 40 was persuasive to the Congress, and the Board was consequently given broad power under $8(a)(2)$ to combat employer interference. ${ }^{41}$ So armed, the Board and the courts began a vigorous enforcement effort, ${ }^{42}$ and the strict per se approach developed quickly.

be treated equally. 29 U.S.C. $\$ 160$ (c) (1970). The Board has followed this directivc. See Carpenter Steel Co., 76 N.L.R.B. 670 (1948); Jack Smith Beverages, Inc., 94 N.L.R.13. 1401 (1951), modified, 202 F.2d 100 (6th Cir. 1953), cert. denied, 345 U.S. 995 (1958). This change is discussed in further detail in Note, Section $8(a)(2)$, stupra note 4 , at 856 .

31. Dale Electronics, Inc., 137 N.L.R.B. 1212, 1216-17 (1962).

32. NLRB v. Philamon Laboratories, Inc., 298 F.2d 176, 181 (2d Cir. 1962), cert. de. nied, 370 U.S. 919 (1962); Aluminum Extrusions, Inc., 148 N.L.R.B. 1662 (1964).

33. 25 NLRB, ANn. Rep. 60 (1960). See also Detroit Plastics Products Co., 126 N.L.R.B. 1182, $1184(1960)$.

34. Ben Corson Mfg. Co., 112 N.L.R.B. 323, 338 (1955).

35. Birmingham Post Co., 49 N.L.R.B. 206, 207 (1943), enf'd, 140 F.2d 638 (5th Cir. 1944).

36. Poe Machine \& Engineering Co., Inc., 107 N.L.R.B. 1372 (1954).

37. NLRB v. Mt. Clemens Metal Products Co., 287 F.2d 790, 791 (6th Cir. 1961).

38. C. Summers \& H. Wellington, Labor LaW 419, 420 (1968).

39. L. Saulny, Independent Unions 25 (1944). See generally R. Dunn, Company Unions (1927).

40. 79 Cong. Rec. 7570 (1935).

41. See S. REP. No. 573, 74th Cong., 1st Sess. 9-11 (1935).

42. For early histories of the enforcement of the provision, see Crager, Company Unions Under the National Labor Relations Act, 40 Mich. L. REv. 831 (1942); Note, Employer. Dominated Unions-Illusory Self-Organization, 40 Colum. L. REv. 278 (1940). See also, e.g., 3 NLRB, ANN. REP. 108-26 (1938). 
Only in light of labor's struggle against the early company unions is the per se rule intelligible. Standing alone, it is not entirely logical; outright employer assistance by itself need be neither detrimental nor improper. In fact, when a labor organization is gratuitously given an office or a typist, that would appear to be a benefit. The per se prohibition on such assistance is understandable only when coupled with the presumption that employer assistance to labor organizations is necessarily subversive to the interests of the employees.

Since many would agree-the unions most vigorously-that the NLRA represented the triumph of one ideology over another, ${ }^{43}$ it is not surprising that there is an entire series of such presumptions implicit in the Act. Some of these presumptions, which together may be called the "adversary model" of labor relations, include: There exists an inherent conflict of interest between employers and employees; this conflict leads to hostility; employers wish to subvert the interests of their employees; no informed employee would align himself with his employer; any organization of employees in which management plays a part is thus necessarily a fraud and contrary to the employees' best interests.

\section{The Need for New Standards}

\section{A. The Decline of the Company Union}

Today, however, the more blatant forms of company unionism have largely disappeared. ${ }^{44}$ While employer attempts to manipuate through assistance continue to pose some problems, ${ }^{45}$ the concept of independently organized labor has achieved general acceptance. Cases involving $\S 8(a)(2)$ are increasingly less common, ${ }^{40}$ and ideological dis-

43. See, e.g., N. Chamberlain, The Labor Sector 125, 120 (1965); W. Spexcer, National Labor Relations ACt 1-5 (1935); T. Slusser, THe Labor ACT-Is it Tolerable? (1939).

44. Most contemporary 8(a)(2) complaints have nothing to do with classic "company unionism." Rather, they are essentially disputes between regular unions over which shall be the certified collective bargaining agent. Thus, current cases typically involve situations in which an employer recognizes a minority union, C. H. Heist Corp., 186 N.L.R.B. No. 57, 76 L.R.R.M. 1062, 1063-64 (1970), or helps one union gain favor over another with his employees, Sturgeon Electric Co., Inc., 166 N.L.R.B. 210 (1967), or continues to check off dues after a union security agreement has expired, Penn Cork \& Closures, Inc., 150 N.L.R.B. 411 (1965).

45. C. SUMmers \& H. WhLlington, supra note 38, at 421; M. Fonkosci, supra note 8 , at 668 .

46. In 1938, 8(a)(2) charges constituted $19.5 \%$ of all unfair labor practice complaints. Between 1941 and 1949, they constituted $9.8 \%$, and between 1961 and $1969,6.3 \%$. By 1970 , the figure had dropped to $4.5 \%$. 1-35 NLRB, ANN. REP. (1936.70) (percentages derived from yearly statistics). 
cussion of the subject has virtually ceased.47 As early as 1953, a former Board chairman declared the company union problem to be "almost dead." 48 The issue, in short, has given way to more pressing controversies.

Simultaneously, other developments have rendered the existence of company unions less threatening. Section 8(a)(2) was not only a pro. tective device for individual workers, but also a means for promoting the growth of organized labor. ${ }^{49}$ Yet as organized labor has achieved maturity, public policy efforts have turned from nurturing unions to limiting and regulating them. ${ }^{50}$ The early threat, actual or perceived, of management's co-optation of the labor movement is no longer a problem.

On this ground alone, it can be argued that it is now inappropriate to follow the stringent per se rule. If the justification for outlawing even non-detrimental assistance lay in the overall threat of massive company co-optation, then, to the extent that company unionism no longer poses such a threat, the law should fashion more subtle standards to differentiate truly detrimental cases of employer assistance from non-detrimental ones. The per se rule, a meat cleaver once appropriate for hacking through the mass of company unions, needs to be replaced with a scalpel for excising occasional malignancies. ${ }^{\text {b1 }}$

\section{B. The Inapplicability of the Adversary Model}

The inadequacy of the per se rule runs even deeper, however, to its very basis in the adversary model. Today, substantial numbers of work-

47. The most recent scholarly commentary on the ideological basis for $\$ 8(a)(2)$ ap. pears to be Note, Section $8(a)(2)$, supra note 4 , which appeared in 1959.

48. Remarks of ex-Board Chairman Herzog, Hearings on $H$. Res. 115 Before the House Comm. on Education and Labor, 83d Cong., lst Sess., pt. 1 at 266 (1935).

49. Contemporary proponents of the Wagner Act were extremely sensitive to charges of fostering trade union monopoly rather than worker autonomy. See remarks of Scnator Wagner in Hearings on H.R. 6288 Before the House Comm. on Labor, 74th Cong., 1st Sess., at 15 (1935), vigorously denying such charges. Nonetheless, shoring up organizcd labor was certainly a predominant goal of the campaign against company unions; to labor sympathizers, employee representation plans portended "the defeat of the trade union-movement." R. DUNn, Company Unions 20 (1927), quoting G. Watk1n, IntroducTION TO THE STUDY OF LABOR PROBLEMS. This vein is occasionally evident in the legislative history. Cf. S. REP. No. 573, 74th Cong., 1st Sess. 11 (1953).

50. The Labor-Management Relations Act, 1947 (Taft-Hartley Act), 29 U.S.C. \$141 ct seq., sets forth a series of unfair labor practices which can be committed by labor orgati. zations themselves. The Labor Management Reporting and Disclosure Act of 1959 (Lan. drum-Griffin Act), 29 U.S.C. \$ 401 et seq., regulates internal union democracy.

51. Judge Wisdom, in his dissent in Walton Mfg. Co. v. NLRB, $289 \mathrm{~F} .2 \mathrm{~d} 177,182$ (5th Cir. 1961), made this point with regard to the Board's dislike of employees' committecs: The Board, with a bull-dog grip, has seized on a policy of unyielding hostility to all employee committees. This method of attacking a problem shows a certain grin dctermination that in some situations is a virtue. It is not a virtue, as this case demon. strates to me, when the Board assumes the policy has a universal applicability the policy does not possess. 
ers no longer have an interest in class struggle politics..$^{52}$ There is a decline in union membership; ${ }^{53}$ strikes are more difficult to organize and maintain; ${ }^{54}$ organized labor has made little headway with white collar employees; ${ }^{55}$ the moral fervor that once drove the movement seems to have died. 50

It has been suggested that changes in technology and in the structure of the labor market have resulted in a corresponding change in the orientation and goals of many workers. ${ }^{57}$ Status, ${ }^{58}$ responsibility to

52. Substantial minorities were never included in the first place. Perennially bejond the adversary model has been the small group of traditional unionists who have become disaffected with organized labor for various personal reasons. See generally $\mathbf{P}$. Sultan, The Disenchanted Unionist (1963). A larger excluded group are cthnic minorities, to whom organized labor has generally shown disinterest or hostility. See generally P. JAcoss, THE STATE OF THE UNIONS $154-91$ (1963).

53. M. EsteY, The UNIONS 3 (1967).

54. J. BeIRNe, ChalleNGe to LABoR 203 (1969). Ross, Labor Organizations and the Labor Movement in Advanced Industrial Society, 50 VA. L. REv. 1359, 1961 (1964), notes that

[t] he proportion of union members involved in stoppages, and the loss of vorking time in relation to the number of union members or the size of the labor force have diminished.

55. P. JACOBS, supra note 52, at 261.

In 1968, only 3.2 million of an estimated 23.3 million unionizable white-collar workers were actually union members, and less than one tenth of one per cent vote themselves into unions each year. E. Curtin (National Industriat CoNference Bo.ArD), Wuite-Collas Unionization 1, 2, 5 (1970). The 3.2 million total represents 16 per cent of all union members. Some unions are attempting to broaden their base among white-collar workers or are, in fact, almost totally composed of white-collar vorkers. Id. at 9, 12. For the most part, however, the AFL.CIO has summarily dismissed the associations that claim the allegiance of white-collar, technical and professional workers as company unions. P. JACOBS, supra note 52, at 281.

56. Ross, supra note 54, at 1366; P. SultaN, supra note 52, at 13.

57. See generally Ross, supra note 54. The change in orientation has been almost universally perceived, although not precisely identified. See, c.g., J. BEanik, supra note 54, at 201; P. Sultan, supra note 52, at 7; P. JACoBs, supra note 52, at 273; J. SeidaAs, J. London, B. Karsh \& D. Tagliacozzo, The Worher Views His Union 2j6, 260 (1969); Strauss, Professionalism d- Occupational Associations, 2 Industrual Relations 14-18 (1963).

The causes of the change are disputed. Increased automation and technologieal change is undoubtedly a factor. Thus, a white-collar worker at a kejpunch maj be doing precisely the type of line production work which would historically have made him a union candidate, but he may nonetheless spurn a union as a lower class device, and see him. self as far removed from traditional class struggle worries over speed-ups and lock-outs.

However, worker rejection of the adversary model is not exclusivcly a white-collar phenomenon, a fact demonstrated by the long history of functioning company unions among blue-collar workers. The breakdown of this model for increasing numbers of blue-collar workers may have been hastened by economic and governmental changes that have eroded the perception of unions as job-protectors, P. Sulran, supra note 52 , at 15, in combination with increasing government willingness to act as emplojment insurer and last-resort employer. The most significant factor, however, may vell be simply the generally greater level of affluence.

While the existence of non-traditional goals is widely recognized, the authors differ over the appropriate labor-management organization which they imply. See, c.g., Surauss, supra, at 14-15, who implies that such workers should be forced into an adversary mold for their own good.

58. It is often argued that the white-collar worker's demonstrated reluctance to join unions is due to a fear of losing status-to a fecling that unions are for bluecollar workers only. Since this attitude has persisted long after the average salaries of blue-collar workers have risen above those of non-supervisory white-collar workers we must conclude that white-collar workers are willing to make cconomic sacrifices to maintain their status.

M. EsTEY, supra note 53, at 82,83 (emphasis added). 
society, achievement, and work satisfaction are goals that white collar and even many blue collar employees often share with their employers, and which may lead them to reject traditional unions. ${ }^{50}$ Instead of viewing themselves as adversaries of management, ${ }^{60}$ contemporary workers often identify with the company. ${ }^{01}$ In contrast to the traditional adversary model, this orientation might appropriately be characterized in terms of a "coalition model." 62 Examples of coalition rather than adversary orientation may be found in the white collar technicians of a university, whose primary allegiance is to the intellectual community; ${ }^{03}$ in the workers of a small and highly specialized company, who appreciate the owner's paternalism; among the secretaries of a large law firm, whose one-on-one employment structure may be most important to them; ${ }^{64}$ or among nurses, who have the same educational background and professional ethic as their supervisors. ${ }^{05}$

While it is clear to commentators that, for workers who view them. selves as somewhere between traditional labor and traditional management, "in-between' policies will have to be worked out,"00 na-

59. In contrast, the paradigmatic production worker and union recruit is characterized by purely acquisitive occupational desires, no commitment to calling, no desire for autonomy, no sense of obligation to turn out high quality work, and, in keeping with the adversary model, little or no sense of identification with the company. Stratuss, supra note 57 , at 11,12 .

60. Research indicates that most American workers put themselves into the middle class, and perceive no particular struggle between themselves and anyone else based on class. Ross, supra note 54, at 1379.

61. Strauss, supra note 57 , at 14 .

62. It is not suggested that the attitudes of the coalition model are ubiquitous anong modern workers, but simply that they appear to be widespread. No idcological modeladversary or coalition-can ever apply to more than a fraction of the labor force. Sce Ross, supra note 54, at 1365.

63. The NLRB has jurisdiction over nonprofit educational institutions. Cornell Unl. versity, 183 N.L.R.B. No. 41, 74 L.R.R.M. 1269 (1970).

64. If the proper jurisdictional requirements are met the Board may order a bargain. ing unit composed of secretaries, $c f$. Hamilton WVatch Co., 118 N.L.R.B. 591 (1956), stenographers, Eljer Co., 108 N.L.R.B. 1417 (1954), or salaried attorneys, Lumberman's Mut. Cas. Co. of Chicago, 75 N.L.R.B. 1132 (1948).

65. The NLRB has decided to exercise jurisdiction over private and proprietary hospltals which receive $\$ 250,000$ in annual gross reventes. Butte Medical Propertics $d / b / a$ Medical Center Hospital, 168 N.L.R.B. 266 (1968). Private nursing homes and related facilities are covered if they receive $\$ 100,000$ in annual gross revenues. Kew Gardens Nursing Home, 194 N.L.R.B. No. 58, 78 L.R.R.M. 1594 (1971). Nonprofit hospitals are exempt from NLRB jurisdiction. NLRA $\$ 2(2), 29$ U.S.C. $\$ 152(2)$.

This comparatively recent extension of national labor regulation to medical institutions may bring into sharp focus the difficulty of imposing an adversary model on coalition. oriented workers. State labor law has sometimes dealt with the problem by relaxing the principle of employer/employee separation in such cases. For cxample, the Connecticut Nurses Association, which is run by supervisory nurses and is therefore "dominated," is nonetheless allowed to represent non-supervisory nurses. No violation has becn found because the nurses desire it that way, and employee free choice is the "tap root" of the applicable labor law. The Waterbury Hospital, Inc., Conn. Bd. L. Rel., Decision No. 89 (1968). See also Southampton Hospital, 30 S.L.R.B. 119, 123 (New York, 1967) (supervisors allowed in same organization as supervisees).

66. Strauss, supra note 57 , at 24 . 
tional labor law has traditionally been locked into a model of labor relations which discourages virtually all labor structures that differ from the traditional adversary-oriented union. ${ }^{\circ 7}$ To the extent, then, that workers identify more with management than with traditional unions, ${ }^{68}$ and that employers are not interested in subverting the interests of their employees, ${ }^{69}$ there is a need to relax the stringent standard of separation that has developed under $\S 8(a)(2)$. What is suggested is not repeal of the existing law, but rather a limited redefinition of an administratively and judicially created doctrine in order to meet the needs of a broader group of employees. ${ }^{\mathrm{T} 0}$

\section{Emergent Standards}

The basis for a more flexible interpretation of $\S 8(a)(2)$ may be found in a line of cases which has already departed from the per se rule. In these decisions, the courts have permitted-under the banner of "co-

67. One alternative is to join the great internationals or associations. . . . Another alternative is the so-called "inside union." ...

The third alternative ... is the right not to join or create or assist any labor

organization at all ....

NLRB v. Sterling Electric Motors, 109 F.2d 194, 201.02 (9th Cir. 1940). What this court sees as three alternatives, however, is really only two: union or no union. The independent local really offers only the limited alternative of freedom from "the machinations of "big union' leadership." Robinson, Structural Characteristics of the Independent Union in America, 19 LAB. L.J. 417 (1968).

Nevertheless, unaffiliated locals have seen rough handling by the Board and by national organized labor. U.S. DEPT. OF LABOR, UNAFFILIATEd LOCAL \&. SiNGLE EMgPLover UNioNS IN THE UNITED STates iii (1967). Perhaps as a consequence, unaffiliated independents account for only $2.6 \%$ of organized labor, or a total of 452,000 members. Id. at 4 . See note 30 supra.

68. P. SULTaN, supra note 52 , at 183 , notes that, in the case of disaffected former unionists, "loyalty to the employer was not . . the automatic response to dislojalty to the union. [The respondents] poured equal scorn on both parties .... An even more cogent example of employees who do not identify with their management is that of teachers. The class struggle militancy of that professional group is an anomaly in terms of the coalition model presented here, but perhaps can be explained by the unique relationship of public school teachers with their municipal emplojers, and their long history of substandard compensation. On the other hand, for a long period teachers were notorious for their willingness to accept wretched working conditions in exchange for relatively high social perceptions. The availability of a coalition model labor organization might allow other white-collar groups to balance these interests, rather than choosing one extreme or the other.

69. It is not simply the worker who is moving away from the adversary model. Employers too "may find it more sensible to accommodate . . . than to perpetuate the tradition of conflict." P. Sultan, supra note 52, at 10. Symptomatic is the increased blurring and overlap between guarded management prerogatives and bargained-over terms and conditions of employment. See Loomis \& Herman, Management's Reserved Rights and the NLRB-An Employer's View, 19 LAB. L.J. 695 (1968); see pp. 515-16 supra.

70. Such a change is appropriately one for the courts to make, rather than the Congress. In the first place, the traditional doctrines of domination and support are themselves court-made and Board-made. Further, an across-the-board legislative change may not be as discriminating as a case-by-case approach in making interstitial changes-especially where, as here, a reinterpretation to cover unusual cases is suggested. 
operation"-labor organizations and employer action which were clearly and admittedly violations under the traditional view of domination and support. Two touchstones emerge from these somewhat confusing cases: actual employer intent to dominate by coercion or manipulation, and actual employee dissatisfaction with the organization in question.

\section{A. Motive: Employer Intent to Coerce}

In the earliest of the "cooperation" cases, Chicago Rawhide Manufacturing Co. $v$. $N L R B, 71$ the employees independently made the decision to form a shop committee, and management assisted them by drawing up ballots and forms, and by helping with the election of officers. $^{72}$ Under existing precedent ${ }^{73}$ the management's action was a clear violation of $8(a)(2)$. The Board so found and issued a cease and desist order. ${ }^{74}$

The Sixth Circuit, in reversing the order, suggested several reasons why the facts in Chicago Rawhide did not constitute a case of support, but rather were an example of cooperation. One of these reasons, it appears, was that the employer did not exhibit improper intent. ${ }^{75}$ The record, said the court, "shows that the Company was not intending . . . to coerce or influence the employees' choice of bargaining representative."76 Introducing the element of intent was a departure from prior 8 (a)(2) cases. ${ }^{77}$ To the extent it was ever discussed in applying the traditional per se rule, intent was deemed to be implicit in the very ac-

71. 221 F.2d 165 (6th Cir. 1955).

72. 105 N.L.R.B. $727,730-31$ (1953).

73. The Board report, 105 N.L.R.B. 727, 735 (1953), cites as atthority Axelson Mfg. Co., 88 N.L.R.B. 761 (1950); American Thread Co., 84 N.L.R.B. 593 (1949); The Carpenter Steel Co., 76 N.L.R.B. 670 (1948).

74. 105 N.L.R.B. 727 (1953).

75. The particular standards applied by the Sixth Circuit in Ghicago Rawhide are far from clear. Although the court appears to depart considerably from the per sc rulc, there is still language in the decision in keeping with the traditional cases.

As noted in the text, the court seems to be emphasizing the element of intent. Yet there is also language in the opinion that suggests the contrary. Thus the court at one point states that support, "even though innocent," is prohibited. 221 F.2d at 167. See note 105 infra.

76. $221 \mathrm{~F} .2 \mathrm{~d}$ at 170 .

77. See note 10 supra. The intent element is less novel in other unfair labor practice areas, although in such cases the standard is specific intent rather than the broader concept suggested here and developed further at pp. 522, 528.29 infra. For disctission of an intent standard in the context of $\$ 8(a)(3)$, see Christensen \& Svanoc, Motive and Intent in the Commission of Unfair Labor Practices: The Supreme Court and the Ficlive Formality, 77 YALE L.J. 1269 (1968); Getman, Section $8(a)(3)$ of the NLRA and the Effort to Insulate Free Employee Choice, 32 U. CHI. L. REv. 735 (1965); Note, Proving an 8(a)(3) Violation: the Changing Standard, 114 U. of PA. L. REv. 866 (1966); Oberer, supra note 3 . 
tions of the employer, ${ }^{78}$ and was certainly not a necessary element of the offense. ${ }^{79}$

The second important "cooperation" case is Coppus Engineering $v$. $N L R B .{ }^{80}$ After an election which the Steelworkers lost, the manager of the plant suggested to the employees "that they have a permanent grievance committee, if that is what they wanted to call it, to handle grievances." $\$ 1$ The committee functioned satisfactorily for a year, using company property and company time, until the Steelworkers filed an 8(a)(2) charge. The First Circuit reversed, citing Chicago Rawhide. The court noted that "[the] evidence shows no more than cooperation by petitioner and a possibility of company control," 82 and that "there is no actual evidence of domination of the Committee by petitioner." 83 The employer's intent appeared particularly relevant to Judge Magruder, who noted in his concurrence that "the record contains no history of anti-union bias by this company," 8 and that

[i]f the employees should freely choose a different bargaining representative, there is no basis in the record for an inference that the company would drag its feet in resistance to recognition of such a new bargaining representative, as the law requires. ${ }^{85}$

Finally, in Modern Plastics $v . N L R B, 80$ the employer provided the employees' committee with all types of secretarial services, and a plant conference room for meetings; paid the committee members during

78. Generally, intent is scrutinized in traditional $8(a)(2)$ cases only when the overt actions are in themselves not conclusive. Thus, although the cmployer's actual behavior in relation to the challenged organization might be ambiguous, it is a violation nonctheless when "the respondent's desire to frustrate organization by the cmployecs in a union of their own choosing is manifest from the circumstances preceding and surrounding its creation." The Nubone Company, Inc., 62 N.L.R.B. 321, 325 (1945). In short, hostile intent is scrutinized to condemn the employer when he is otherwise not in violation of even the per se standard of domination and support, but benign intent is not available as exculpatory evidence under any circumstances. See note 10 supra. But cf. Note, Section $\delta(a)(2)$, supra note 4 , at $361 \mathrm{n} .69$, which suggests that intent may have played an unexpressed role in all $\$ 8(\mathrm{a})(2)$ cases.

There is some suggestion, however, that if the emplojer has a benign intent, the Board's order must be limited to disestablishment only, rather than a generalized order to obey the Act. NLRB v. Empress Publishing Co., 312 U.S. 426, 435-36 (194I); NLRB v. Jas. H. Matthews \& Co., 156 F.2d 706, 710 (1946); Northeastern Engineering Inc, 112 N.L.R.B. 743 (1955).

79. "No proof of coercive intent or result is necessary to establish an [8(a)(2)] unfair labor practice on the part of the cmployer." Int'l Union, Progressive Mine Workers of America v. NLRB, 319 F.2d 428, 436 (7th Cir. 1963), rev'd mem. on other grounds, 375 U.S. 396 (1963).

80. 240 F.2d 564 (lst Cir. 1956).

81. Id. at 567 .

82. Id. at 573 (emphasis added).

83. Id. at 572.

84. Id. at 573 .

85. Id. at 573-74.

86. 379 F.2d 201 (6th Cir. 1967). 
meetings; paid for dinner and drinks; was present at committee meetings; suggested operating procedures; and gave advice on elections. ${ }^{87}$ The Board found these actions to be domination, and ordered the committee disestablished. The Sixth Circuit, however, after again stressing its perceived difference between cooperation and domination, reversed, saying:

It is true that the acts rendered might be the means by which the Company could exert pressure, but we do not find any substantial evidence in the record that it was so used by the Company. . . .
$[\mathrm{T}]$ he record contains no showing of anti-union bias by the Company ${ }^{88}$

Thus, absent a showing of employer bad faith, assistance alone is not per se violative.

Although the cooperation cases are not entirely clear or consistent, the standard they suggest for a $\S 8(a)(2)$ violation is employer assistance tainted by an intent to coerce. Such a standard properly focuses on the employer's bad faith, his willingness to use manipulation and coercion as means of adjusting industrial differences, ${ }^{80}$ his designed ${ }^{00}$ and willful ${ }^{91}$ denial of the rights of employees under the Act.

As the cooperation cases demonstrate, there are numerous instances in which an employer might wish to maintain or assist a labor organization without having any intent to coerce. Aside from the obvious examples of well-meant personal gifts, Christmas parties, free meals, and occasional use of company equipment, an employer might wish to maintain an employees' committee as a "channel of communication," or as a more equitable and efficient way of settling grievances. If, for example, a university should set up a grievance committee for its labo. ratory technicians after they have rejected an outside union, and if the university's motives are its desire to have some sort of functioning information conduit despite insufficient initiative among the employees, ${ }^{93}$ there would seem to be no national labor policy objective served

87. Id. at 202,203 .

88. Id. at 204 .

89. Cf. Blackman, Relative Severity of Employer Unfair Labor Practices, 22 LAu. L.J. 67, 68 (1971).

90. Cf. NLRB v. Buitoni Foods Corp., 298 F.2d 169, 174 (3rd Cir. 1962).

91. Cf. Federal-Mogul Corp. v. NLRB, 394 F.2d 915, 920 (6th Cir. 1968)

92. Social science and industrial management literature always stresses the inportance of "keeping open lines of communication." See, e.g., L. Adams, MAnagental l'sycholocir 357 (1965). It is odd that this literature can virtually ignore the legal problems which such communication can present. See, e.g., H. Albers, Princirles of Organization ANd Management 212-13 (1965).

93. The worker in any case will often be a client. See Ross, supra note 60, at 1960. The organization may be a union run by a professional union hierarchy, or, like fore. men's clubs and secretarics' guilds, may be run by the employer. 
by disestablishing the council, at least if the technicians are satisfied with it. ${ }^{94}$ On the other hand, if General Motors should organize and maintain an employees' association with the plan of ousting the United Auto Workers, then clearly GM has rejected the basic premises of the NLRA. Because employer assistance is indisputable in each case, both plans would be struck down under the traditional per se rule. ${ }^{05}$ The application of the intent to coerce standard, however, would eliminate the abusive organization while sparing the non-detrimental one. ${ }^{.8}$

\section{B. Free Choice: Employee Dissatisfaction}

The other element suggested in the cooperation line of cases is employee choice and satisfaction. Previously, although many $8(a)(2)$ cases had been decided in the name of preserving the Act's guaranteed freedom of choice, ${ }^{97}$ the opinions of the employees actually involved in the case had been considered irrelevant. ${ }^{98}$ Chicago Rawhide, however, in refusing to disestablish an organization which satisfied the employees concerned, gave content to employee satisfaction as a measure for domination and support. "The test of whether an employee organization is employer controlled is not an objective one, but rather subjective, from the standpoint of the employees." 99 While similar language had been used in the past, the courts had never been clear as to what it entailed. ${ }^{100}$ To the Chicago Rawhide court, however, this test seems to

94. The standard of employee satisfaction is discussed at pp. 523.25 infra.

95. There are no 8(a)(2) cases dealing with universities, presumably becuuse the Board has only recently extended jurisdiction to them. See note 63 supra. Howeser, it scems clear that the Board, given its hostility to employees' committees, would not allow cither of the hypothetical organizations to stand. See pp. 513.14 supra.

96. Factors to be considered in applying the intent to coerce standard are considered further at pp. 528-29 infra.

Not all would agree that a standard based on the emplojer's intent is workable. See Note, I1 U. KaNs. L. REv. 281, 283 (1962) (commenting on the cooperation cases).

97. See, e.g., NLRB v. The Summers Fertilizer Co., 251 F.2d 514 (Ist Cir. 1958); NLRB v. Wemyss, 212 F.2d 465 (9th Cir. 1954). In these cases, the supposed infringement of freedom of choice is based more on judicial conjecture than on actual evidence.

98. Thus, in NLRB v. Newport News Shipbldg. \& Drydock Co., 308 U.S. 241, 248 (1939), which was decided in the name of emplojec free choice, the Court ordered disestablishment although a "sweeping majority" of the employecs desired to have the challenged organization continue. See also cases cited in note 11 supra.

99. 221 F.2d at 168.

100. This standard had been mentioned beforc, but seemingly gratuitously; it apparently had never been applied to sustain a challenged organization. See, e.g., Tappan Stove Co. v. NLRB, 174 F.2d 1007 (1949), which gare expression to this principle of sub. jective domination yet disestablished an inside committec claining the allegiance of $\$ 37$ of 516 employees in the presence of a "long history of friendly labor relationship between the respondent and its employees." Id. at 1009. See also Sharples Chemical Co. v. NLRB, 209 F.2d 645 (6th Cir. 1954); NLRB v. Thompson Products, 130 F.2d 363, 368 (6th Cir. 1942); Feldman \& Steinberg, Employee-Management Committees and the Lolor Mionagement Relations Act of 1977, 35 TUL. L. REv. 305, 372 (1961). Other commentators hate agreed that the honest application of this standard is incompatible with a per se ap. proach. See The Developing Labor Law 138 (C.J. Morris ed. 1971).

Most cases seem to have followed the Supreme Court's early disinterest in subjective 
mean that any amount of assistance is permissible provided the employees do not feel hampered. Employer control, the court suggests, exists only when the labor organization begins to deviate from the will of the employees. ${ }^{101}$

Similarly, in Coppus Engineering, Judge Magruder said:

No doubt, strong argument could be made that the [shop committee which the Board had found dominated] was an inherently weak bargaining representative, and a feeble instrument for conducting bitter economic warfare, as contrasted with a union affiliated with a strong national labor organization. But it may be that the employees at this particular plant did not feel the need of any different type of bargaining representative. The choice was theirs, and the Act guarantees to them freedom to exercise that choice, unimpeded by employer interference or coercion. ${ }^{102}$

This standard of employee satisfaction was also made explicit in Modern Plastics. Noting that the challenged organization had been operating for ten years to the satisfaction of all but the complaining Machinists' Union, the court quoted with approval, and apparently adopted as its ratio decidendi, a remark by the Trial Examiner:

I am persuaded by the credible evidence of witnesses called by both parties to this proceeding that despite the unlawful character of the Committee and despite Respondent's unlawful intrusions into its affairs, nevertheless the employees whom the Committee represents have derived considerable benefit from its representations and none have been shown to have been dissatisfied either with the Committee itself or with the particular type of representation it provided them. ${ }^{103}$

In short, the Sixth Circuit found that the actions of management did not constitute domination because the court did "not find any sub. stantial evidence in the record that it . . . was so considered by the employees." 104

cmployee satisfaction, see p. 513 supra, and to have felt that "[n]o proof of cocrcive . . . result is necessary to establish an unfair labor practice on the part of the employer." Int'I Union, Progressive Mine Workers of America v. NLRB, 319 F.2d 428, 436 (7th Cir. 1963), rev'd mem. on other grounds, 375 U.S. 396 (1963). In the face of language such as this, the distinction drawn by the cooperation cases between "actual" and "potential" domination is a substantial departure. See, e.g., Chicago Rawhide Mfg. Co. V. NLR1, 221 F.2d 165, 170 (7th Cir. 1955).

101. See also NLRB v. Keller Ladders Southern, Inc., 405 F.2d 663 (5th Cir. 1968). "So long as the acts of cooperation do not interfere with the freedom of choice of the cm. ployees, there is no violation of the Act." Id. at 667 (cmphasis added).

102. $240 \mathrm{~F} .2 \mathrm{~d}$ at 573 (concurring opinion) (emphasis added).

103. 379 F.2d at 203 (emphasis modified).

104. Id. at 204. 
This approach seems well within the spirit of the NLRA. Since employee freedom of choice is an underlying goal of the Act, the satisfaction or dissatisfaction of employees should be a controlling factor. Yet under the traditional per se rule, the law, instead of guaranteeing freedom to choose, imposed a solution.

It should not, however, be assumed that the standards suggested by the cooperation cases have been universally recognized. ${ }^{105}$ The more traditional per se approach continues to guide the Board ${ }^{108}$ and, frequently, the courts. ${ }^{107}$ Nevertheless, these cases have found some acceptance, and the elements discussed above have been weighed in upholding $^{108}$ or disapproving ${ }^{109}$ challenged organizations.

\section{Adoption of the Emergent Standards}

The greatest barrier to adopting the new standards delineated here arguably lies in inferences which may be drawn from actions by Congress and the Supreme Court. During the debate preceding the TaftHartley amendments, Congress did consider an alteration of the traditional domination and support rule. The House bill contained a pro-

105. The standards discussed here are not immediately apparent from any one of the cooperation opinions; moreover, the cases themselves still display the class-struggle rhetoric of more traditional cases. For example, by denominating as "cooperation" the actions of management in what are really joint ventures between emplojer and employee, the courts perpetuate the myth that the employees' committees are wholly independent labor organizations.

An explanation for the ambiguity of the cooperation opinions might be that they were not conscious of breaking new ground. For example, in scrutinizing the cmplojer's intent, or in giving more than mere lip service to employec frec choice, the cooperation opinions may have understood themselves simply to be searching for the determinative factor in a close case. See note 78 supra.

106. See, e.g., St. Joseph Lead Co., 171 N.L.R.B. 545 (1968); Newman.Green, Inc, 161 N.L.R.B. 1062 (1966); Framco, Inc., 158 N.L.R.B. 111 (1960).

107. See, e.g., NLRB v. Clappers Mffg., Inc., 458 F.2d 41.4 (3rd Cir. 1972); NLRB v. Ampex Corp., 442 F.2d 82 (7th Cir. 1971), cert. denied, 404 U'S. 939 (1971); Schwarzenbach-Huber Co. v. NLRB, 408 F.2d 236, $256-57$ (2d Cir. 1969), cert. denied, 396 U.S. 960 (1969). In NLRB v. Reed Rolled Thread Die Co., 432 F.2d 70 (Ist Cir. 1970), the court ordered disestablishment of an employees' committec; stating that the case vent "bejond" its earlier decision in Coppus Engineering, the court hcld that

the contentions of respondents that the emplojees have apparently been satisfied

with the arrangement, having twice voted down an outside union, that there has

been an absence of labor strife and anti-union bias do not command an opposite result.

Id. at 71 .

108. Lake City Foundry Co. v. NLRB, 432 F.2d 1162 (7th Cir. 1970); Federal-Mlogul Corp. v. NLRB, 394 F.2d 915 (6th Cir. 1968); NLRB v. Coca-Cola Bottling Co., 333 F.2d 181 (7th Cir. 1962); Hotpoint Co. v. NLRB, 289 F.2d 683 (7th Cir. 1961); Kimbrell v. NLRB, 290 F.2d 799, 802 (4th Cir. 1961).

109. NLRB v. Keller Ladders Southern, Inc., 405 F.2d 663 (5th Cir. 1963); NLRB v. Walton Mfg., Inc., 289 F.2d 177 (5th Cir. 1961). See also NLRB v. Buitoni Foods Corp., 298 F.2d 169 (3rd Cir. 1962) (employer bad faith used to justify cease and desist order); Utrad Corp. v. NLRB, 454 F.2d 520 (7th Cir. 1971) (specific finding of anti-union motive used to distinguish cooperation line and justify disestablishment). 
posed $\S 8(d)(3)$, which would have permitted assisted labor organizations by allowing the

[f]orming or maintaining by an employer of a committee of employees and discussing with it matters of mutual interest, including grievances, wages, hours of employment, and other working conditions, if the Board has not certified or the employer has not recognized a representative as their representative under section 9.110

According to the House Report, this section was designed to

permit employers whose employees have not designated a bargaining representative to set up . . . committees and to discuss with them wages, hours, working conditions and other subjects of collective bargaining as well as other matters of mutual interest. ${ }^{111}$

The Senate version did not include this provision, however, and it was eliminated in conference. ${ }^{112}$ Subsequently, in $N L R B$ v. Cabot Carbon Co., ${ }^{113}$ the Supreme Court clearly rejected the suggestion that the intent of this deleted provision was effectively encompassed by other Taft-Hartley amendments: 114 "This argument treats the [situation] as though Congress had adopted, rather than rejected as it did, the pro. posed $\S 8(\mathrm{~d})(3)$ advocated by the House."115

110. H.R. 3020, 80th Cong., 1st Sess. $\$ 8(\mathrm{~d})(3)$ (1947), reprinted in 1 NLRB, LeGisLativE History of the Labor-Management Relations Act, 1947, at 31, 56 (1948).

111. House Rep. No. 245, 80th Cong., 1st Sess. 33, reprinted in 1 NLRB, Legislative History of THE Labor-ManageMient Relations ACT, 1947, at 292, 324. (1948).

112. The Conference Report stated:

This provision is omitted from the conference agreement since the Act by its terms permits individual employees and groups of employees to meet with the employer and section $9(a)$ of the conference agreement permits employers to answer their grievances.

H.R. REP. No. 510, 80th Cong., 1st Sess. 45 (1947).

113. 360 U.S. 203 (1959).

114. It was Cabot's contention that the proper reading of the Taft-Hartley anuend. ment to $\$ 9$ (a) must logically exclude employees' committees from the class of labor organizations, and therefore prohibitions against domination and support of labor organizations do not apply. 360 U.S. at $214-15$. The $\S 9(\mathrm{a})$ amendment added to the proviso in the original Act which read:

Provided, That any individual employee or a group of employees shall have the right at any time to present grievances to their employer.

the addition:

and to have such grievances adjusted, without the intervention of the bargaining representative, as long as the adjustment is not inconsistent with the terms of a collective bargaining contract or agreement then in effect; Provided further, That the bargaining representative has been given opportunity to be present at such adjustment.

29 U.S.C. $\$ 159(\mathrm{a})$.

115. 360 U.S. at 217. Unmoved by Cabot's arguments of constructive legislative intent, the Court held that the definition of "labor organization" covers employecs' committces, since Congress inserted the term "dealing with" into the NLRA's definition of "labor organization" to extend it to more than traditional unions. See note 4 supra. 
Despite this apparent aversion of both the Court and Congress to assisted labor organizations, there are a number of distinguishing factors which render these past judgments inapplicable to the present problem. First, Cabot Carbon was not technically addressed to the broader issue of whether some assisted labor organizations could be acceptable under certain conditions. Instead, the argument was directed, and the opinion was confined, to the narrower issue of whether assisted employees' committees are properly called labor organizations under the Act. On this point, the opinion was clearly correct in deciding that they were so included, and there is thus no need to overrule the holding of Cabot Carbon in order to apply the standards suggested here. Indeed, the suggested standards are premised on the assumption that employees' committees and other assisted employee groups are labor organizations, in that the revised standards, being an interpretation of $8(a)(2)$, would apply only to labor organizations. Second, to the extent that the rejection of $\S 8(\mathrm{~d})$ (3) may be interpreted as a policy determination by Congress, it is far from clear that it was an endorsement of the per se rule of $8(a)(2)$. The traditional doctrine of domination and support was judicially and administratively-not legislatively -developed, and the failure of Congress to provide contrary legislation does not necessarily preclude the courts from reevaluating a doctrine they have created. ${ }^{116}$

\section{Application of the New Standards}

The utility of permissibly-assisted labor organizations to employees and to national labor policy will depend, in practice, on the diligence of the Board and the courts in applying the proposed standards of employer intent and employee dissatisfaction. ${ }^{117}$ Once a complainant succeeded in demonstrating either that the employer's intent is to subvert, shackle, or dilute the employees' rights, or that the employees are not content with their present situation, the Board would be justified in finding an 8(a)(2) violation. Only where there is genuine employee satisfaction and an absence of employer hostility should management

116. Cabot Carbon has come in for heavy criticism. Petro, Labor Relations Law, 3j N.Y.U.L. REv. 732, 765 (1960), terms the NLRB view affirmed in the case a "pogrom" against employees' committees.

117. In reality, the first application of these standards would be by the Ceneral Counsel of the NLRB. In his independent prosecutorial discretion, he might refuse to issue a complaint in an $8(a)(2)$ case where intent to cocrce and cmplojec discatisfaction vere patently missing. 
be permitted to form or support a labor organization.118 Thus, the complainant should be required to prove (1) the existence of a labor organization, and (2) some assistance by the employer, as he is now, plus either (3) employer intent to coerce, or (4) employee dissatisfaction.

\section{A. Factors Evidencing Intent to Coerce}

Determining the motivation of the employer will necessarily involve circumstantial evidence. A previous history of anti-organizational activity or unfair labor practices may, for example, indicate an intent to coerce. ${ }^{119}$ Other objective factors from which such an intent might be inferred include: whether the assisted labor organization was hastily established coincidentally with an outside union's organization drive; ${ }^{120}$ whether substantial progress has been made toward settlement of contested issues; ${ }^{121}$ whether the employees are required to participate in the assisted organization or are prohibited from joining an outside union; ${ }^{122}$ whether the company has objected to, or sabotaged, subsequent representation elections; ${ }^{123}$ whether the assisted organization has sought exclusive representation, a closed shop, or a contract barring elections; and whether the organization has in other ways failed to contribute to the essential goals of the Act in assuring workers' rights and industrial tranquillity.

Other factors which are in themselves inherently neutral as to intent, but which have been used in the past to support 8(a)(2) violations, would now be relevant only to the issue of assistance. ${ }^{124}$ These include employer attendance at meetings; employer-provided office space,

118. Section 8(a)(2) prohibits domination of and interference with both the "administration" and "formation" of labor organizations. See note 1 supra. Howcver, most of the case law dealing with $\$ 8(a)(2)$ is concerned with unlawful administration rather than formation. The reason for this appears to be the six month statute of limitations, NLRA $\S 10$ (b), 29 U.S.C. $\$ 160$ (b), which frequently puts the actual formation of the organizat. tion beyond the reach of the union's stit. Of course, the standards suggested here would apply equally to both formation and administration.

119. Cf. NLRB v. Buitoni Foods Corp., 298 F.2d 169 (3rd Cir. 1962), where assistance to a grievance committee followed weeks of anti-union threats, and coincided with physical violence and discriminatory discharges.

120. Cf. NLRB v. Keller Ladders Southern, Inc., 405 F.2d 663 (5th Cir. 1968), where an assisted union was presented to the employecs in "an atmosphere of haste" and forc. closed another union's organizational drive.

121. Cf. NLRB v. Chicago Rawhide Mfg. Co., 221 F.2d 165, 167 (6th Cir. 1955), where substantial disputes were resolved.

122. Cf. NLRB v. Walton Mfg. Co., 289 F.2d 177, 181 (5th Cir. 1961), where cxclusive acquiescence in a proposed employees' committee would have been a condition of em. ployment.

123. Cf. Lenscraft Optical Corp., 128 N.L.R.B. 807, 826 (1960), where the cmployer attempted to sabotage a Board election so that an assisted organization would win.

124. Of course, the character of the assistance might in some cases be evidence of in. tent to coerce, but the element of intent is conceptually distinct fiom the clcment of assistance. 
equipment, or legal services; employer-drafted by-laws; meetings on company time; and financial assistance. ${ }^{125}$

\section{B. Factors Evidencing Employee Dissatisfaction}

The clearest case of employee discontent, and by far the most convenient administratively, is a conclusive demonstration through an official election where the employees reject the assisted organization. ${ }^{120}$ Once $30 \%$ of the employees become disaffected they may, under the terms of the Act, force such an election. ${ }^{127}$ An elective determination would be almost self-executing. If the employees vote for a regular union, it becomes by law the exclusive collective bargaining agent, ${ }^{228}$ and the assisted organization is thus displaced. If, on the other hand, an alternative to the employees' committee does not receive a majority, then no conclusive determination of employee dissatisfaction has been made out for an 8(a)(2) complaint. ${ }^{120}$ Inasmuch as a permissibly-assisted labor organization should not be allowed to enter into a contract barring elections, ${ }^{130}$ the election process could occur yearly if employee sentiment so dictated.131

In the absence of an election, the complainant would have to employ other means to demonstrate employee discontent to the Board. ${ }^{132}$

125. Compare cases cited in notes 12-26 supra.

With regard to the provision of financial assistance, a strict reading of $\$ 8(a)(2)$ sug. gests that the per se rule is partially written into the Act, and that consequently no in. quiry into intent is necessary to find a violation on the basis of such assistance. That is, the three forbidden actions are "dominate," "interfere," and "contribute," and while the first two arguably imply an intent standard, the last does not. See the complete text at note I supra. However, such a reading appears to be inconsistent with the purpose of the section, which is to protect labor organizations. Mforcoser, it seems poindless to construc this simple section in two different ways at once. Although the legislative history does not illuminate the issue, the purpose of "contribute" is evidently to specify a particular type of domination or interference. Thus, the most natural reading of the last clause may be "or contribute financial or other support to it [in order to dominate or interfere with it]," which invests the intent requirement into the whole provision. Cf. Titan Mfetal Mfg. Co. v. NLRB, 106 F.2d 254, 260 (3rd Cir. 1939), cert. denied, 308 U.S. 615 (1939).

126. It appears to be within the Board's discretion to include upon the ballot such non-traditional options as workers' committees and employees' representation plans, although the Board has generally declined to exercise that discretion. See NLRB v. Falk, 308 U.S. 453 (1939); 32 NLRB, ANN. REP. 90-91 (1967).

127. NLRA $\$ 10(c), 29$ U.S.C. $\$ 160$ 'c) $(1970)$.

128. NLRA § 9(a), 29 U.S.C. \$ 159(a) (1970).

129. The governing standard of discontent should continue to be majoritarian, as it has since the earliest beginnings of the Iabor movement. See generally Schreiber, The Origin of the Mfajority Rule and the Simultaneous Development of Institutions to Protect the Minority: A Chapter in Early American Labor Law, 25 Rurcers L. REv. 237 (1971). The argument that a majority standard may result in a company union being foisted on a desperately unhappy $49 \%$ is unpersuasive: first, minorities are frequently dissatisficd even with traditional unions, and second, unlike a statutory collective bargaining agent imposed upon a minority, permissibly-assisted labor organizations would not be allowed to act on behalf of dissenting employees. See pp. 530-31 infra.

130. See pp. 530-31 infra.

131. NLRA \$ 9(c)(3), 29 U.S.C. \$ 159(c)(3).

132. Since assisted labor organizations such as employees' committces are frequenty ad hoc organizations which come into existence to fill a suddenly perceived vacuum left 
It would obviously be difficult to call in troops of employees and question them in a structured hearing setting. In general, it would probably be simpler for the complainant to base his 8(a)(2) action on employer intent. Nevertheless, there are criteria that would be appropriate in determining whether a majority of the employees are dissatisfied with their assisted organization: whether a traditional union has recently been rejected in a fair election; ${ }^{133}$ whether the organization has existed for some time without labor unrest; ${ }^{134}$ whether informal polls indicate employee dissatisfaction; ${ }^{135}$ whether substantial issues of fair representation have been pressed by dissident employees; ${ }^{130}$ and whether the employees participated in establishing and maintaining the organization. ${ }^{137}$

\section{Safeguards and Remedies}

Since permissibly-assisted labor organizations are exceptions to the longstanding rule of complete separation between labor and management, they should not be allowed to displace or threaten traditional unions. It is arguable that allowing some employers to form "company unions" will surely encourage bolder abuses by truly hostile employers. While to some degree concerns such as these would be avoided by the standards suggested here, the Board should also use its discretionary power ${ }^{138}$ to ensure that such organizations, while tolerated, have only limited authority. That is, there should be a dif-

by the defeat of an outside union, they typically do not cxist as alternatives in an initial election. Therefore, not having a conclusive demonstration of employec discontent, and perhaps not wishing to wait a year until a new election can be ordered, an outside union might conceivably wish to proceed administratively with its $8(a)(2)$ charge.

133. Cf. Ferguson-Lander Box Co., 151 N.L.R.B. 1615 (1968), where in two stuccessive "clean" elections the employees voted down outside unions in order, by implication, to stay with the employees' committee. The committee was nonetheless discstablishcd.

134. Cf. NLRB v. Post Publishing Co., 311 F.2d 565 (7th Cir. 1962) (38 years of har. mony with an assisted labor organization); Hotpoint v. NLRB, 289 F.2d 683 (7th Cir. 1961) (30 years with an assisted organization); NLRB v. Summers Fertilizer, 251 F.2d 514 (Ist Cir. 1958) (assisted organization lasted one month before all employecs struck).

135. Cf. NLRB v. Magic Slacks, Inc., 314 F.2d 844, 847 (7th Cir. 1963), where an unim. peached poll showed 47 to 3 in favor of the employees' committee.

136. Since permissibly-assisted labor organizations would not have the normal statt. tory rights to represent dissenting employees, see p. 531 infra, the compulsory nature of majoritarian collective bargaining, which serves as the basis for fair representation cases, would not be present. However, situations are nevertheless conceivable in which such an organization could be arbitrarily acting to harm a minority, as where its leaders promote discriminatory policies. While this logically goes to the level of employec satis. faction, to the extent that the employer permitted such discrimination it would also go to his intent to coerce.

137. Cf. Erikson d/b/a Detroit Plastics Co., 114 N.L.R.B. 1014 (1955).

138. The Board has broad remedial discretion, NLRA $\$ 10(a), 29$ U.S.C. $\$ 160$ (a) (1970). In $8(a)(2)$ cases this has most commonly been exercised in deciding between a cease and desist order and total disestablishment. See note 2 supra. 
ference in legal status between a traditional union and a permissiblyassisted labor organization.

In order to avoid foreclosing the entry of a traditional union, the employees should have considerable freedom to oust any employerassisted organization. This can be guaranteed by requiring that no agreement made by an assisted organization could bar a representation election. ${ }^{139}$ Similarly, no assisted organization should be able to act on behalf of anyone but its own members. ${ }^{140}$

By discretionary use of its remedial powers, the Board could further tailor the characteristics of assisted organizations. For example, in an ambiguous case, even though an 8(a)(2) violation warranting disestab. lishment is not proven, the Board might nevertheless wish to provide that the challenged organization may not become the exclusive bargaining agent, negotiate a closed shop, enforce the employer's duty to bargain, or bring suit on any agreement. Through the Board's application of the two standards proposed here, and through its discretionary powers, traditional unions could therefore be assured their basic right under the law: the right to be chosen by the employees where the employees genuinely want them. ${ }^{141}$ At the same time, the employees would remain free to join any organization they choose, including one in which management plays a part.

\section{Conclusion}

Under traditional 8(a)(2) standards, employees had only two organizational alternatives-either a full-fledged traditional labor organization, divorced from the employer and committed by law to the adversary model, or no organization at all. While this Note has suggested

139. The contract bar rule is administrative, so its alteration would present no problem. In such circumstances elections could be held annually if needed.

140. Such a result could be achieved by enforcement policy. For example, since any assisted organization which attempts to act for non-members demonstrates the employ: er's impermissible intent to coerce as to those employees, it is therefore an 8(a)(2) vio. lation. See p. 528 supra. Therefore, the Board could issue an appropriate cease and desist order. More directly, the Board might promulgate this requirement-or, indeed, any safeguarding requirement for permissibly-assisted labor organizations-as a regulation to govern the conferring of employees with emplojers as it is empowercel to do by the proviso in $\$ 8(a)(2)$. See note I supra. The Board has never exercised this power.

141. A good illustration of what the permissibly-assisted labor organization discussed here could be like is to be found in foremen's organizations. Decmed by the law, NLR.1 $\$ 2(3), 29$ U.S.C. $\$ 152(3)$, to be professionals, foremen have not been protected from "domination" of their organizations. As a consequence, such organizations hase typically been formed, funded, and perpetuated by management, and, in teeping with the appar. ent sympathies of their members, have offered various programs of professional improvement. Despite such interference, many foremen enthusiastically particupatc, and their assisted organizations have helped them in presenting their grietances. Strauss, supra note 57 , at 17 . 
a third option because of changes in the labor environment since the early days of the Wagner Act, other alternatives exist as well. For example, experiments in "industrial democracy" have successfully lowered worker alienation by increasing employee decision-making power. ${ }^{142}$ Viewed as the incursion of labor into the realm of management prerogative, ${ }^{143}$ industrial democracy is of particular interest because it represents the converse of employer domination. Though well beyond the scope of this discussion, ${ }^{144}$ the possibility of such additional alternatives further emphasizes the basic point developed here-that employer-employee co-participation must be judged in light of the particular context in which it occurs.

142. The term "industrial democracy" has a checkered background, many secing it as a cuphemism for "company union." M. Derber, THE AMERICAN IDEA OF INDUSTRIAL DEMOCRACY, 1865-1965, at 355 (1970). However, to industrial psychologists it is a neutral term for reforms related to the fact that "there is hardly a study in the entire literature which fails to demonstrate that satisfaction in work is enhanced or that generally acknowl. edged beneficial consequences accrue from a genuine increase in workers decision-making power." P. Blumberg, Industrial Democracy 123 (1968). See generally E. RHENMAN, Industrial Democracy and Industrial Management (1968). Some success has been reported in Germany's codetermination program, and France's tripartite plan. P. BLUM. BERG, supra, at 2. Also see generally N. DAs, EXPERIMENTS IN INDUSTRIAL DEMOCRAGY (1964); A. Shuchman, Codetermination: Labor's Midde Way in Germany (1957).

143. See Loomis \& Herman, supra note 69.

144. It is noteworthy, however, that reported failures in this type of broad cooperative industrial relationship seem to stem from precisely the two negativing standards suggested here-either employer bad faith or employee dissatisfaction. Thus, where the cm* ployees are displeased, industrial democracy is a failure. P. Blumberc, supra note 142, at 8. Similarly, in the United States during World War II, many of the labor-management committees promoted by the War Production Board failed largely because of the tension between workers and managers. D. DE SCHWFinitz, LABOR AVD MANAGEMENT in A CoMMON ENTERPRISE 156.57 (1949). Although stuck institutionally into a cooperative mold, the participants, who were usually local union officials, reacted in terms of the adversary model. 